\title{
Research on Cultural Heritage and Industrial Development of Southern Shandong Folk Arts and Crafts
}

\author{
Lijuan Feng \\ Elementary Education Department \\ Linyi University \\ Linyi, Shandong, China, 276000 \\ e-mail: flj1972@163.com
}

\begin{abstract}
Southern Shandong folk handicraft is famous for its long history and colorful manifestations in Shandong. It carries Southern Shandong people's yearning for a better life and pursuit for the truth, goodness and virtue, and reflects Southern Shandong people's attitude to life, aesthetic emotion and art spirit. Impacted by the culture of the new generation in a global context, it is of great urgency to protect and transmit excellent folk arts and crafts. The author suggests to protect and to develop the folk arts and crafts through making protection, policy-oriented and developmental strategies, giving policy support, implementing industrial development in market and carrying out art education in school and other ways in order to achieve the transmission and industrial development of Southern Shandong folk arts and crafts.
\end{abstract}

Keywords—southern Shandong folk handicraft; folk arts and crafts; cultural inheritance and industrial development

\section{INTRODUCTION}

Southern Shandong folk arts and crafts is rooted in the fertile soil of Southern Shandong culture, and it is a traditional art created by ordinary working people to beautify life, convey ideal and enrich folk activities. It carries Southern Shandong people's yearning for a better life and pursuit for the truth, goodness and virtue, and reflects Southern Shandong people's attitude to life, aesthetic emotion and art spirit. It has become an important carrier for the research of Southern Shandong culture, history, economy and folk life. Currently, with the rapid rise of Southern Shandong's economy, people's pace of life increasingly accelerates and their economic awareness is intensified. Impacted by various new cultural arts, the traditional handmade folk arts and crafts is increasingly being shelved and forgotten. A large number of precious historical and cultural works and skills are being deserted or running off. Some outstanding craft forms, such as embroidery, dyeing, weaving, etc. may soon disappear for folk artists of older generation are going to pass away and there are no inheritors. Therefore, it has become an important topic of the cultural management departments at all levels and the artists to research Southern Shandong folk arts and crafts' form, content, cultural connotation and aesthetic characteristics, promptly sort out outstanding folk arts and crafts resources, integrate the local economic development, cultural inheritance, arts education in school, and form a cultural industry with Southern Shandong regional characteristics and a school-based textbook suitable for teaching and practice.

\section{THE HistORICAL INHERITANCE AND THE DEVELOPMENT STATUS}

Southern Shandong folk arts and crafts is an outstanding art created by Southern Shandong people in the long-term working and living. It carries Southern Shandong people's yearning for a better life and pursuit for the truth, goodness and virtue, and reflects Southern Shandong people's attitude to life, aesthetic emotion and temperament and spirit. Now, it has become an important carrier for the research of Southern Shandong culture, history, economy and folk life. For this reason, it is a premise of the protection, transmission and development of the Southern Shandong folk arts and crafts to research the historical inheritance and development status of Southern Shandong folk arts and crafts, sort out its historical context and understand the survival and development status.

\section{A. The Historical Inheritance Situation}

Southern Shandong has a long history and lots of talents gather here. This place not only has brilliant and distinctive regional historical culture, but also has gave birth to a numerous of diversified and connotational folk arts and crafts. According to archaeological discoveries, 30,000 years ago as early as the Upper Paleolithic, Southern Shandong ancestors lived and bred in this ancient land, and have left rich prehistoric cultural relics, including the microlithic cultural relics found in Yihe River and Shuhe River basin in the 1980s, Piyi Wazidi ruins, and stone tools, potteries and bronzes unearthed from Linshu Beigoutou ruins, which have provided valuable cultural relics data for us today to study the source of Southern Shandong folk arts and crafts. In the middle of last century, archaeologists found a lot of portrait stones in the tombs of Han Dynasty in Linyi and silk paintings, potteries and lacquerware of Western Han Dynasty unearthed from Yinqueshan Han Dynasty Tomb and etc. With its rich cultural inheritances, precious historical value 
and high artistic achievement, they become outstanding representatives of Southern Shandong folk arts and crafts and the witnesses of the long history.

\section{B. The Current Development Status}

1) The basic situation: Southern Shandong folk arts and crafts resources are widely distributed, in various art forms and with a broad mass base and distinctive regional artistic characteristics. Currently, the municipal and county-level cultural management departments have sorted out and documented more than forty types of Liyin folk arts and crafts. Among them, the most famous works are folk papercut of Tancheng Matou, Cangshan blue prints, Hedong color prints, Yishui Gaoqiao hand embroidery, Linshu wickerwork, Junan stone carving, Cangshan Xiaoguo clay sculpture and Tancheng wooden toys. These works have ever won national awards repeatedly, so they have a great influence and are sold at home and abroad. Currently, three items of Linyi folk arts and crafts have been selected into Shandong Intangible Cultural Heritage Catalog; more than ten items of folk arts and crafts have been selected into Linyi Intangible Cultural Heritage Catalog. Fan Jimei Inheritor of Tancheng Wooden Toys has been selected as the inheritor of Shandong intangible culture. Xiang Wenyou Inheritor of Blue Prints and other four folk artists have been selected as the inheritors of Linyi intangible culture.

2) Difficulties and problems: For a long time, the development of Southern Shandong folk arts and crafts is still stuck in a relative scattered pristine state because of the relatively closed geographical environment in the Southern Shandong mountainous area and the craftsmanship. It doesn't form a certain scale and lacks appropriate protection and transmission mechanisms. Most of folk arts and crafts creations are still stuck in a self-sufficient or small-business closed mode, except for stone carving, wickerwork and toys produced in a large scale with an early commercialized start. The art transmission mostly relies on dictation and personal teaching from older artists. The traditional crafts scattered in the folk do not receive timely finishing and protection, and folk artists have not been given due attention and support. Especially in recent years, with the further enhancement of globalization, the traditional culture and arts are strongly impacted by the culture of new generation. The folk arts and crafts based purely on handmade workmanship has been abandoned by younger generation for it consumes much time and energy, and is of low economic efficiency. As a result, it faces difficulties that there is no inheritor and the folk arts and crafts may disappear. A numerous of valuable historical and cultural works and workmanships are being deserted or lost. Therefore, it has become an urgent priority to excavate and sort out folk arts and crafts data scattered in Southern Shandong timely, and protect and transmit outstanding folk arts and crafts.

\section{REGIONAL DistRIBUTION AND ARTS AND HUMANITIES CHARACTERISTICS}

\section{A. Various forms and wide regional distribution}

Southern Shandong folk arts and crafts has a diversity of artistic forms, and at present, more than 40 artistic forms have been registered in cultural administrative departments at city and county levels. Southern Shandong folk arts and crafts can be classified by production processes and materials into several major categories, such as paper cutting, fabric crafts, sculpture, painting, silk figure and so on.

1) Fabric crafts: The folk fabric crafts, one of the forms of folk arts and crafts, refers to everything made from textiles, including spinning, dyeing and finishing, embroidery, clothing, fabric toys, etc.. Southern Shandong folk fabric crafts, known as a folk collective art form, has a long history and extensive mass base in southern Shandong mountainous region. In the days of material scarcity, the intelligent women after laboring in southern Shandong mountainous region used to spin their home-grown cotton and dye the cotton cloth to make clothes, bedclothes, ornamentation and so on for all members of their families, and fabric crafts thus became an important factor to measure the ability of the local females to manage a household.

2) Paper cutting: Southern Shandong paper cutting has enjoyed a good reputation for its rustic style and vibrant simplicity and has extremely extensive mass base in southern Shandong. In southern Shandong mountainous region, all households cut "Chuang Hua" (meaning window flowers) and hang Men Jian (a decorative paper-cut for luck and happiness) at the doors to create a strong festive atmosphere every Spring Festival. “喜” (pinyin: $\mathrm{Xi}$, meaning "happy") can always be seen at weddings to decorate the wedding room and all kinds of wedding supplies in order to express people's best wishes for newlyweds. Since southern Shandong folk paper cutting is mostly used during festivals, wedding and other happy occasions, it thus prefers auspicious omen-themed flowers, birds, fishes, insects and figures as the subject and tends to use homophone, metaphor and other techniques to indicate people's wishes for happiness and peace, for example, "fish swimming through lotus" meaning happy marriage, "peony pomegranate" meaning wealth and more sons, "pine, crane and cloud" meaning health and longevity, etc.

3) Sculpture: Southern Shandong sculpture covers stone carving, wood carving, clay sculpture, ceramic sculpture, dough sculpture and so on and is mainly distributed in Ju'nan, Linshu, Yi'nan, Cangshan, Feixian and other counties, among which, Wangjiafang Qiancun Village in Ju'nan County is famous for the stone carving technique in China and was named as the "Home of China' s Stone Carving" by the national Ministry of Culture in 2009. Its stone carving for gardens, stone carving for building and stone carving as crafts are of ingenious design and sophisticated technology and have been classified into eight 
major categories and more than 5,000 varieties and sold at home and abroad.

4) Weaving: Southern Shandong weaving mainly includes wickerwork, string weaving, rattan plaited articles and so on, among which, the weaving techniques in the area of Ju'nan, Hedong, Tancheng and Linshu and Chinese knot string-weaving techniques in Honghua Town, Tancheng County are the most prestigious. The purple osier, widely grown within Linyi and the basin of Linyi River and Shuhe River, is the main raw material for the production of southern Shandong wickerwork owing to its pliability, uniform thickness and elegant luster, and it can be woven into a variety of beautiful, light, durable and useful crafts through different techniques.

\section{B. Rich Humanistic Connotation and Colorful Artistic Features}

1) Rich historical and cultural connotation: Southern Shandong has a long history and is notable as a cradle of brilliant talents and one of the important birthplaces of Chinese civilization. As early as 400,000 to 500,000 years ago, ancestors in southern Shandong had created wealthy historic culture. Abacus inventor Liu Hong in Eastern Han Dynasty, strategist Zhuge Liang in the Three Kingdoms period, sage of calligraphy Wang Xizhi in Eastern Jin Dynasty, calligrapher Yan Zhenqing in Tang Dynasty and many other celebrities and masters of past ages had lived here and left deep cultural imprint. The long history and profound cultural accumulation not only nourishes hardworking and talented people in southern Shandong, but nurtures the folk arts and crafts rooted in the region of southern Shandong. The Ju'nan stone carving has a long history and can be dated back to the late Paleolithic era, and the national secondary relics "stepped adze" and "millstone stick" unearthed locally can be traced back to over 5,000 years ago. The famed paper cutting technique in Matou Town, Tancheng County, originating in the Southern and Northern Dynasties Period of more than 1,500 years ago, has a profound cultural meaning and illustrates the local people's wishes for lucky years and eternal peace. The inkstone-manufacturing technique in Yi'nan and Feixian counties has been popular for a very long time and was highly praised by the famous calligraphers Yan Zhenqing, Su Shi, Wang Xizhi in past dynasties. In addition, Hedong dyeing, Gaoqiao embroidery, Linshu wickerwork and other folk arts and crafts are all notable for their long history and profound cultural accumulation, showing the beauty of the combination of form with meaning.

2) Simple, natural, fresh artistic features: The artistic idea of "passion for simplicity and nature" is the highlight in southern Shandong area. Southern Shandong mountainous region is relatively geographically isolated, far away from the flashy urban environment and independent of cultural and historical background, people here are simple and honest. The folk artisans hold the aesthetic ideology of "abandon luxury, advocate simplicity and nature" , so the southern Shandong folk arts and crafts, influenced by this ideology, is mostly hand-made. For material selection, many local natural materials which are easily available, such as a willow branch, a handful of loess and so on, can be made into artworks; for decorative technique, it prefers to keep the original shape of the material rather than add excessive embellishment in order to create a simple rustic style and natural charm. The simple artistic idea and aesthetic concept of folk artisans in southern Shandong have a profound effect on the pattern, meaning and creative practice of the folk arts and crafts, and based on this, the simple, natural and fresh regional artistic style is established for southern Shandong folk arts and crafts.

\section{BASIC STRATEGY AND IMPLEMENTATION APPROACH}

\section{A. Basic Strategy}

1) Protective Strategy: The southern Shandong folk arts and crafts is confronted with adverse conditions as a result of the scattered distribution of arts and crafts resources, serious loss of original data and poor transmission and development, and for this reason, the priority shall be given to the folk craft forms which have higher cultural and artistic value, or face survival difficulty and are endangered due to the lack of successors, and emergency measures for protection and development of the above craft forms shall be taken, including data mining, artwork collection, craft video and so on. Systematic and complete text, image and video documents and long-term protection mechanism shall be established, in particular, if the folk artisans of some folk crafts are old and fail to find their successors, cultural administrative departments at all levels shall make investigations and interviews, collect artworks, videotape the whole technological process, sort out detailed text and video images, and on this basis, perform culture propaganda, academic research and school education to popularize the folk arts and crafts among younger generation for the purpose of the effective protection and transmission of endangered folk arts and crafts.

2) Developmental Strategy: In view of the current circumstance where the material and content of southern Shandong folk arts and crafts can hardly meet the new generation of young people's aesthetic demand due to its relatively onefold pattern, backward production technology, it is thus preferable to focus on the folk art forms which are close to the modern life and have potential for development and practical value, and such folk arts and crafts shall be supported and developed as an important industry to promote its economic and cultural value, enhance its market competitiveness and increase the artisans' profits. On the other hand, the folk artisans shall be encouraged to attach importance on the innovation and development of patterns, materials and themes of folk arts, embrace the advanced techniques and design ideas on the basis of learning and inheriting the tradition and add new cultural and aesthetic 
meaning to the traditional folk art so as to promote the innovative development of southern Shandong folk arts and crafts in the new era.

\section{B. Implementation approach}

1) Policy support and cultural management: Southern Shandong folk arts and crafts is an integral part of the regional cultural of southern Shandong and is the precious resource to promote local economic and cultural development. Governments at all levels and cultural administrative departments shall fully understand its important value and current difficulties, establish systematic and complete mechanism of protection, transmission and development of southern Shandong folk arts and crafts through policy guidance, cultural management, popularization and other forms and provide necessary policy support and fund for the transmission and development of the traditional folk arts and crafts. Cultural administrative departments at all levels shall give full play to its management function, conduct a census of the local folk artisans and register the forms of folk art in detail, establish systematic intangible cultural heritage archives for the folk art and implement routine and dynamic management of transmission and development of all kinds of folk arts and crafts in order to completely change the ungoverned primitive living condition of southern Shandong folk arts and crafts and promote its well-regulated transmission and sound development.

2) Market-oriented industrial development: The development of industrial market is an effective form to promote the transmission and development of southern Shandong folk arts and crafts in the new era. Based on the local market investigation, the priority shall be given for resource integration and industrial development to some of folk art forms with higher economic and cultural value or large market demand, including dyeing, embroidery, toys and so on, so that the traditional distributed production can be transformed into scale production. The all-in-one folk arts and crafts limited company for production, supply, marketing and research shall be set up and associated with the local economy and cultural brand construction to further expand its market space and enhance its economic and cultural value. It is supposed to establish a series of southern Shandong folk arts and crafts cultural industries with brand effect, which can not only promote the local economic and cultural construction, but helps realize the characteristics transmission and industrialized and large-scale development of the folk arts and crafts.

3) Art education in schools: School education is one of the most fundamental forms of transmission of folk art. According to the principles of education and teaching in school, priority shall be given to the excellent art forms which are positive, of high artistic, cultural and aesthetic value and close to life so as to develop folk arts and crafts school-based curriculum which is applicable for teaching practice. Appreciation and creation teaching shall be conducted for students, which can not only improve students' ability for appreciation and creativity, but helps realize the effective transmission and sustainable development of folk arts. Furthermore, students are supposed to accept unconsciously the artistic edification and aesthetic education when exposed to the strong cultural atmosphere in campus through holding regular exhibition of folk arts and crafts, inviting folk artisans to campus or organizing art creation competition, and will consciously learn, protect and transmit southern Shandong folk arts and crafts.

\section{CONCLUSION}

Southern Shandong profound historical and cultural inheritance and simple folk custom have cultivated Southern Shandong people with "industrious and brave, selfless and dedicated" outstanding characters, meanwhile give Southern Shandong folk arts and crafts profound humanistic spirit and "simple and natural, naïveté-advocating" artistic thought. For relatively dispersed resources and unsound protection and transmission mechanism, Southern Shandong folk arts and crafts lack development strength. On the on hand, the local government and cultural management departments should intensify policy advocacy and protection strength, conduct a comprehensive survey and register for their folk arts and crafts resources, and vigorously publicize Southern Shandong folk arts and crafts and fully excavate, sort and protect them through confirming folk arts and crafts inheritors, reporting and selecting the intangible cultural heritage from folk arts and crafts and holding folk art exhibition. On the other hand, it is needed to further increase capital investment, establish a virtuous folk art economic mode and protection mechanism, give folk artists necessary economic support and honor incentives, integrate Southern Shandong folk arts resources into school education and educate the younger generation about folk arts and attract more young people dedicated to folk art protection and transmission, and thus promote the healthy development of Southern Shandong folk arts and crafts.

\section{REFERENCES}

[1] Pan Lusheng \& Zhao Yi et al. Survey Report on Shandong Rural Cultural Industry - Crafts in Village [M]. Shandong People's Publishing House, 2008. 11.

[2] Zhu Zhengchang \& Gao Tingyun. Qilu Characteristic Culture Series ${ }^{\circ}$ Crafts Category [M]. Shandong Friendship Press, 2004.

[3] Li Qun. Traditional Art [M]. Shandong Friendship Press, 2008. 8.

[4] Liu Fan. Study on Aesthetic Characteristics of Chinese Folk Toy Cloth Tiger [J]. Art and Design (theory), 2011. 4.

[5] Gong Chuhan. Discussion on Aesthetic Emotion of Folk Embroidering Pouch [D]. Chinese Outstanding Master's Thesis, 